\title{
ENTREPRENEURSHIP EDUCATION AT UNIVERSITY: INNOVATIVE MODELS AND CURRENT TRENDS
}

\author{
Aistė Čapienė, Aistė Ragauskaitė \\ Aleksandras Stulginskis University, Lithuania \\ aiste.capiene@asu.lt; aiste.ragauskaite@asu.lt
}

\begin{abstract}
Entrepreneurship education is a relevant topic in today's study programs of higher education at two levels: as research object and as development of skills while preparing students. In fact, the latter is one of the most important objectives in Lithuanian universities aiming together with other disciplines at developing students' entrepreneurial skills. The main aim of the article is to analyze theoretical and practical models of entrepreneurship education applied in universities and introduce development trends. Teaching process involves various methods, internships, consultation and instruction, but usually all activities are not systematically applied. From the behavioral perspective, this study analyses students towards entrepreneurship through the opportunity identification, motivational factors, information source, resources impact and entrepreneurial ability. Hypothetical deductive approach was used through a population sample of 194 students of Aleksandras Stulginskis University Faculty of Economics and management. The research summarized in this paper students attitude toward motives, factors encouraging and preventing entrepreneurship and information sources in the higher education institutions. The gap between teaching methods and student attitude towards at entrepreneurship educations can be reduced supplementing collaboration among stakeholders in the entrepreneurship education. In final part of the article, trends of entrepreneurship education in university enabling to assess dimensions of the development of entrepreneurship education are presented.
\end{abstract}

Key words: entrepreneurship, higher education institutions, entrepreneurship, models and methods of entrepreneurship education.

\section{Introduction}

In Lithuania promotion and development of youth entrepreneurship are based on provisions determined by the European Union (Resolutions of the Government of the Republic of Lithuania, 2012). Entrepreneurship of young person is highly prioritized, because young people have a great potential and are able to create new job opportunities as well as to ensure overall economic growth (Youth Opportunities Marketing, 2015). Also, promotion of entrepreneurship and establishment of new ventures is one of the most important objectives of Lithuanian economic policy - in the third part of the first point of National Progress Program 2014 - 2020 the following objective is determined 'To promote leadership, youth and children entrepreneurship and preparation for the labor market' (Resolutions of the Government of the Republic of Lithuania, 2012). Entrepreneurship is a key factor for economic growth therefore, it is necessary to prioritize initiatives raising public awareness and development of entrepreneurial competences. Entrepreneurship education is implemented while using various methods, theories, models and measures. All applied Lithuanian measures (Youth Entrepreneurship Valuation Toolkit, 2013) promoting youth entrepreneurship can be classified into two large groups: development of entrepreneurial competences ('soft elements') and assistance for business development ('hard elements'). 'Soft elements' teaching, motivation, education, consultation and other activities of a similar nature. 'Hard elements' - measures, which directly or indirectly subsidy business ('start-up' finance, various tax concessions for business development, credits, etc.)

Despite the fact that entrepreneurship education is prioritized in Lithuanian economic policy (Resolutions of the Government of the Republic of Lithuania, 2012), ways and measures to promote youth entrepreneurship are often still to be searched. Gegieckienè \& Grikšienè (2009) stated that entrepreneurship is innate and acquired human quality allowing person to operate actively and be not afraid to risk. However, after analyzing theoretical literature related to entrepreneurship, it can be concluded that the issue regarding personal qualities promoting entrepreneurship is relevant. Driessen \& Zwart (2010) distinguishes 4 main elements regarding entrepreneurship: knowledge, skills, motivation, personal qualities.

There are many different views in scientific literature how entrepreneurship education should be organized and which methods are most effective. According to Ansari et al. (2014), it is important to select what kind of education programs should be applied, that they would develop thinking and encourage them to take actions as well. The essence of this theory is to connect knowledge and experience in the way that these elements would become a clear base for further development or, in other words, there would not be necessity to start again from the beginning. One of the most important ideas is that entrepreneurship can be taught (Rae, 2014); however, it must be applied to specific economic situations and 
circumstances. While organizing learning process it is important to use knowledge regarding innovations, technologies and best practical examples. Lahm \& Rader (2014) states that technological platforms, social networks play an important role in strategy of entrepreneurship education. Ji \& Zhao (2014) distinguished main components of entrepreneurship education in educational institutions. The system is composed of: (a) students, (b) teachers, (c) 'carrier' and (d) environment.

Saeed, Muffatto \& Yousafzai (2014) after researches with 805 students in various universities in Pakistan have proved that practical entrepreneurial activities at university made a positive influence towards the process of entrepreneurship education. This process should involve students in those tasks, which promote self-efficacy, risk-taking propensity and innovation development. Täks el al. (2014) after qualitative research performed with engineering students, described four categories of entrepreneurship education directions: (a) first step toward self-directed learning, (b) preparation for work life, (c) path to selfemployment and (d) context for developing leadership and responsibility for team achievement. Ortega et al. (2014) analyze entrepreneurship education while paying attention to the implementation of various projects, trainings, examples of prominent persons and knowledge creation. Sánchez (2011) raises several important questions related to relations between entrepreneurship and education: what is the meaning of entrepreneurship education? Is entrepreneurship education the same as training for enterprise establishment? How it differs from gaining business education? What relation is between teaching business peculiarities and learning in business enterprise? Do the programs of entrepreneurship education influence entrepreneurial activities?

Entrepreneurship education begins from the development of human creativity, learning to plan and organize, goal achievement, problem solution and innovations (Gamez, 2013). Entrepreneurship education enables students to adapt more easily in dynamic business world and they can become employees who help enterprises compete in the world (Singh \& Magee, 2001). This can be achieved while using such measures as trade games, imitations, business conferences, consultations on business examples, forums, seminars, business platforms and laboratories (Herrera, 2010). In the phase of primary education, the objective of entrepreneurship education would be to strengthen the capacity for creativity; help to understand risk and planning. In secondary school - to develop business thinking, which would help to establish and control enterprise starting from small steps. In colleges and universities, the important factors are interdisciplinarity, work with others and development of various business forms: business, social business, public sector, entrepreneurship, etc. It is important to develop the capacity to analyze economic, social, cultural, technological environment and suggest new ideas. Personal competences: social sensitivity, goal achievement, self-confidence, perception amplitude, empathy, conceptual thinking, decision making and action orientation. Entrepreneurship education involves four stages: entrepreneurship on theoretical level - early stage of academic programs, generation of creativity and ideas - middle stage, business - social plan and support - final stage. Entrepreneurship is a learning process, which continues throughout life; it begins at home while watching examples of parents and other persons, continues in primary and secondary schools, university and even after graduation of continuing education (Pérez, 2014). Higher education can develop human capacity to control, move from ideas to actions, identify possible problems. Businessman as the founder and manager of enterprise seeks to ensure stability while using various methods and styles for making decisions.

University assesses the educational process throughout interaction with students while analyzing their reactions, imitativeness and desire for continuous improvement. Model of entrepreneurship education at university includes three stages (see Figure 1). Traditional methods for entrepreneurship education such as seminars, trainings, lectures, events and etc., form the first stage of model in economic based on knowledge. In order to stimulate behavioral changes and development of psychological characteristics necessary for entrepreneurship, other stages of the model are oriented towards actions and practical tasks. Tools for simulating the development of new business, for instance, business plans, creating and thinking about them together with mentors and consultants, allows to go successfully to the third stage. Students have to be encouraged to participate in national and international contests for developing ideas, broaden their professional horizons and create partnership of business projects. Entrepreneurship promotion and support is prepared quite well at school level in Lithuania; however, it is almost not applied in institutions of higher education. It is a significant gap while paying attention to the role of universities in organizing education and transferring knowledge and scientific researches to the business community and preparing students for labor market. Opportunities to acquire basics of entrepreneurship in institutions of higher education for students are not coherent and not compatible with efforts to organize entrepreneurship education in secondary school. Thus, despite the fact that the educational institutions are autonomous, politicians have a task to convince Lithuanian 


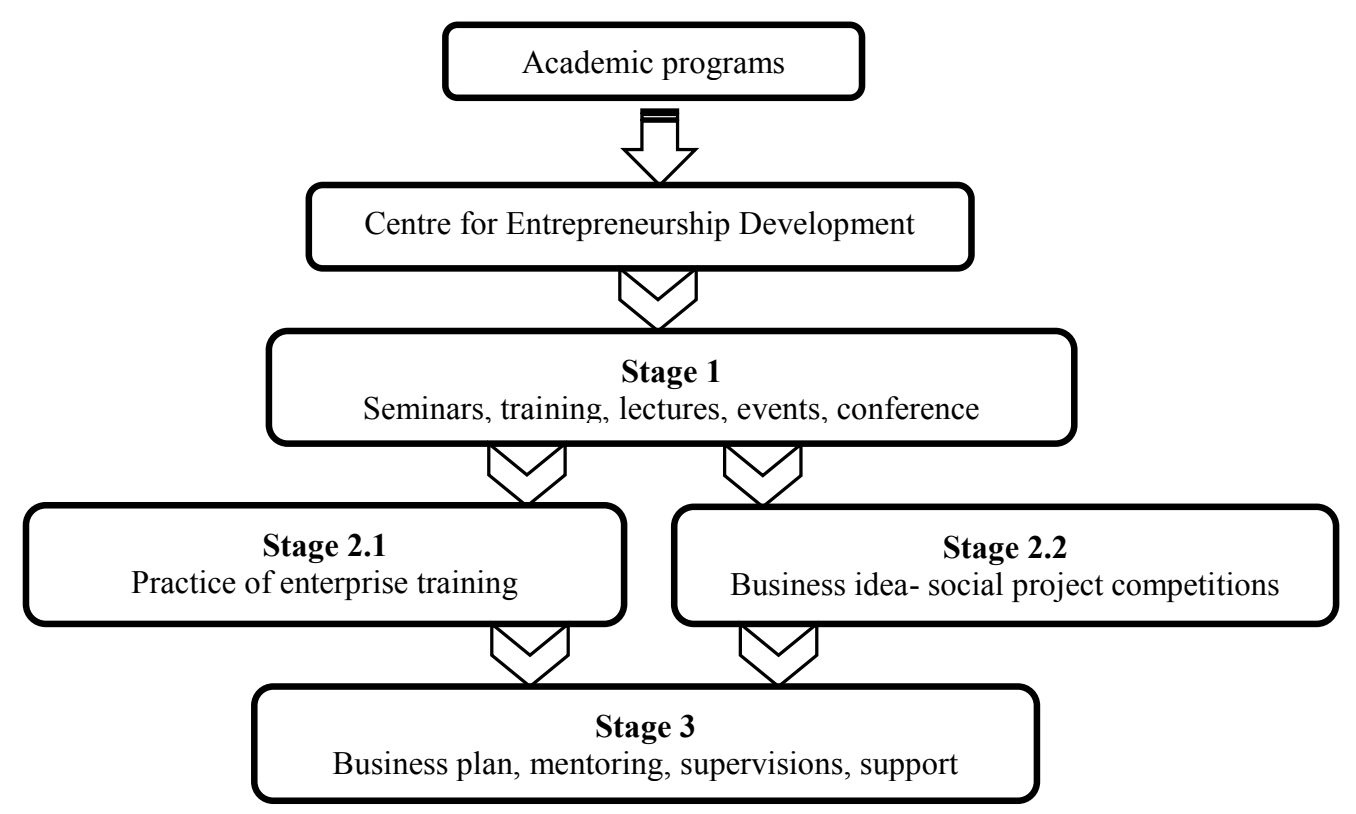

Figure 1. Model of Entrepreneurship Education at University (developed by the authors).

institutions of higher education that entrepreneurship promotion and support are necessary and useful for students and educational institutions as well.

It is necessary to pay attention to the fact that all measures, programs and suggestions for entrepreneurship education have to encourage people to start their own business. However, general scientific researches show that business establishment raises a number of fears and has an evident connection between acquired knowledge and motivation to become businessman. Thus, it can be stated that, in order to conduct research, the main priority was to identify students' motivation to connect their lives with business world. If the students have a low need to become businessmen, measures of entrepreneurship education can be ineffective. However, the suggested general model can help for each student to find out his or her value. Therefore, specific models can be applied only in that case if students believe in what they are doing. Clear framework and informatively presented entrepreneurship opportunities can motivate students to participate actively and become involved in certain activities promoting entrepreneurship.

Research problem - practical models of entrepreneurship education applied in universities while educating students.

The research task - to determine the tendencies of development of entrepreneurial competences in universities and application of their principal patterns among students.

\section{Materials and Methods}

In order to estimate entrepreneurship education at university, students of the Faculty of Economics and
Management of Aleksandras Stulginskis University were chosen. In addition, two researches were conducted. Firstly, case analysis was performed for the sake of identification of activities related to promotion of students' entrepreneurship at the faculty. The analysis covered period running from 2014 to 2016 inclusive (three years). Case analysis helped to indicate initiatives and performed actions in relation to promotion of students' entrepreneurship. This method helps to analyze situation and identify necessary factors for further research, because it is appropriate to complement data with quantitative research (Žydžiūnaitė \& Sabaliauskas, 2017). During the second research, students of the first cycle full-time studies were interviewed. The goal of interviews was to find out whether activities and initiatives carried out influence students' entrepreneurship. It is necessary to pay attention to the fact that questions in questionnaire are generalized and let to analyze the situation. Sample survey include 194 students (Kardelis, 2016), 375 students in total are studying in the first cycle full-time studies, research bias $5 \%$, sample survey was calculated according to Kasnauskienè (2010). Questionnaire was established while following researches conducted by the scientists in the field of entrepreneurship education. The conducted research and presented results can be called the first research which is aimed to learn students' attitude. It is appropriate to analyze each component included in the model of entrepreneurship education separately in further research.

Method of case analysis was used to analyze measures of entrepreneurship education applied in the first and second cycles full-time studies at 
the Faculty of Economics and Management of Aleksandras Stulginskis University. After the analysis, it was determined that measures of entrepreneurship education can be classified into several groups:

- Seminars. 35 seminars on the promotion of entrepreneurship have been organized since 2014. The main tendency of these seminars: the main focus is on invited guests, who tell about their business experience. Today's business leaders participate in these seminars. Also, seminars are organized around certain topics - from generation of business ideas to commercialization of produced products. After the analysis of the lists of the participants, it can be stated that there were averagely 50 students participating in each event.

- Business idea competitions. Business idea competitions are organized annually. In 2014 - 1 competition, 2015 - 1 competition, 2016 - 2 competitions. Average number of received ideas -12 . Not only students but as well as pupils are invited to participate in business idea competitions. Competitions are closely connected with seminars - firstly, thematically seminars are suggested, later participants of competitions are registered and finalists make presentations to the panel. Participants of the business idea competitions have already prepared business plans, their products are already developed or in the process of development. This indicates a high level of entrepreneurship of students participating in these competitions.

- Programs of business education integrated in studies. Students of the first and cycle full-time studies have already a subject "Entrepreneurship"; later, business studies and analysis continue in other subjects. During the last study years, students use their entrepreneurial knowledge in the subject Practice of Entrepreneurship Education. While studying this subject, students work in enterprise simulation, get acquainted with finance management and production management. Also, all students wanting to try themselves can run the company.

After performed case analysis it can be stated that in the Faculty of Economics and Management of Aleksandras Stulginskis University entrepreneurship education is being implemented in coherent and intensive way (i.e., business idea competitions are included in annual action plan, subjects and entrepreneurship practice are included in study program, function of seminars and other organized events on the topic of entrepreneurship is appointed to the Entrepreneurship Development Center) and it involves up to 500 students every year.

The second research is aimed to estimate students' motivation for being businessman and analyze their information channels, which provide them with information regarding programs of entrepreneurship development; in this way, the first element of the model of entrepreneurship education is analyzed and students' need for entrepreneurship is assessed. To present quantitative descriptions in a manageable form was used Descriptive Statistic method. The first group of questions was composed of respondents' demographical data. In the research participated 108 females and 86 males. Respondents' age $19-$ 25 years old. The study uses Likert-type five-point scale. The second group of questions was composed of 9 statements - respondents were asked to estimate statements from 1 (totally disagree) to 5 (totally agree). Statements represent the following question: what kind of motives would encourage respondents to establish their own business?

\section{Results and Discussion}

Respondents estimated every statement; in order to assess the value of statements, point averages were calculated. Students defined a possibility to earn money as the most important motive for business establishment (4.2 points). The statement about financial success is in the second place (4.1 points).

Also, the respondents relate entrepreneurship to carrier possibilities in business world (4.0 points respondents agree with this statement). The most evident negative evaluation is related to business establishment for solving societal problems (2.2 points). As a result, it can be concluded that a possibility to solve societal problems is not relevant to this group of respondents. However, if the respondents would establish their business, they would act while following their values (3.9 points). Answers related to business oriented towards a solution of a specific problem or changing standing practice were estimated similarly - averagely 3 points and in grading scale this means neither 'I agree' nor 'I do not agree'. In scientific literature it is emphasized that motivation for entrepreneurship can be realization of personal competences; thus, respondents were able to share their opinion regarding this statement. However, the respondents' opinions were different - the majority of respondents agreed with this statement. According to the theoretical overview, entrepreneurship has to be oriented towards a solution of a specific problem; however, this research shows that respondents are not sure about the reliability of this statement and answers distributed between positive and negative evaluations.

In addition, other questions related to the measures, which have to be taken in business, also provided 
Willingness to earn money and become rich

Financial success

Carrier possibilities in business world

Willingness to foster values

Willingness to show your personal skills

Wish to solve a specific problem

To from activities of similar people

Willingness to change standing practice

Willingness to solve social problem

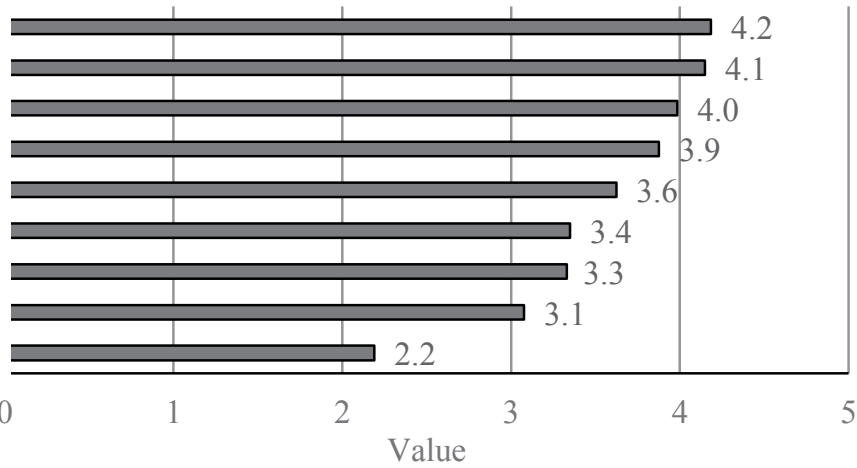

Figure 2. Students' Attitude towards Motives Encouraging Entrepreneurship.

a lot of information. The main goal was to find out respondents' opinion. 8 statements were presented, they were estimated from 1 (totally disagree) to 5 (totally agree).

After analyzing respondents' answers, it can be stated that motivation for business establishment is a very important factor - average of respondents' estimation is 4.7 points. Also, according to the respondents, it is very important to have a good business idea for business establishment (4.7 points). The third important factor is a good team (4.4 points). In theoretical analysis, it was emphasized that knowledge is very important for business establishment. The conducted research has shown that respondents put this statement in the fourth place ( 4.3 points), and in the fifth place is a need to consult with experienced businessmen (4 points). The aim of this group of questions was to estimate what is more important for respondents: support from family or support from friends. The research revealed that respondents appreciate more support from family (3.6 points) than from friends (3.1 points). However, it can be noted that the statement about money relates to the statement presented the first group of questions - money is an important factor for business establishment, according to the respondents (3.7 points).

In the theoretical part of the article and case analysis, various events, seminars and other knowledge sources were defined as important elements in entrepreneurship education. Thus, respondents were asked to estimate 10 information sources from 1 (totally disagree) to 5 (totally agree) while answering the questions from the fourth group.

Respondents define the internet as the most important information source (4.2 points), also, as a more specific information source for entrepreneurship, social networks can be identified (4.0 points). Moreover, they stated that a lot of information related to business is transmitted by the teachers during the lectures (4.1 points). Case analysis has shown that many events related to entrepreneurship education are organized at university and respondents defined them as information source for entrepreneurship (3.8 points). Summarized research results show that newspapers (2.3 points), magazines (2.4 points), books ( 2.3 points), teachers (2.2 points) and school events ( 2.3 points) are not supported by respondents. Information sources estimated by 2 points or less correspond to the statement 'I do not agree'. To sum up, respondents use internet and information provided by the teachers during lectures.

In the last question respondents were asked to estimate 16 statements and those statements, which were estimated by outstanding points, are discussed further. As the main statement respondents excluded knowledge - if they would have enough knowledge,

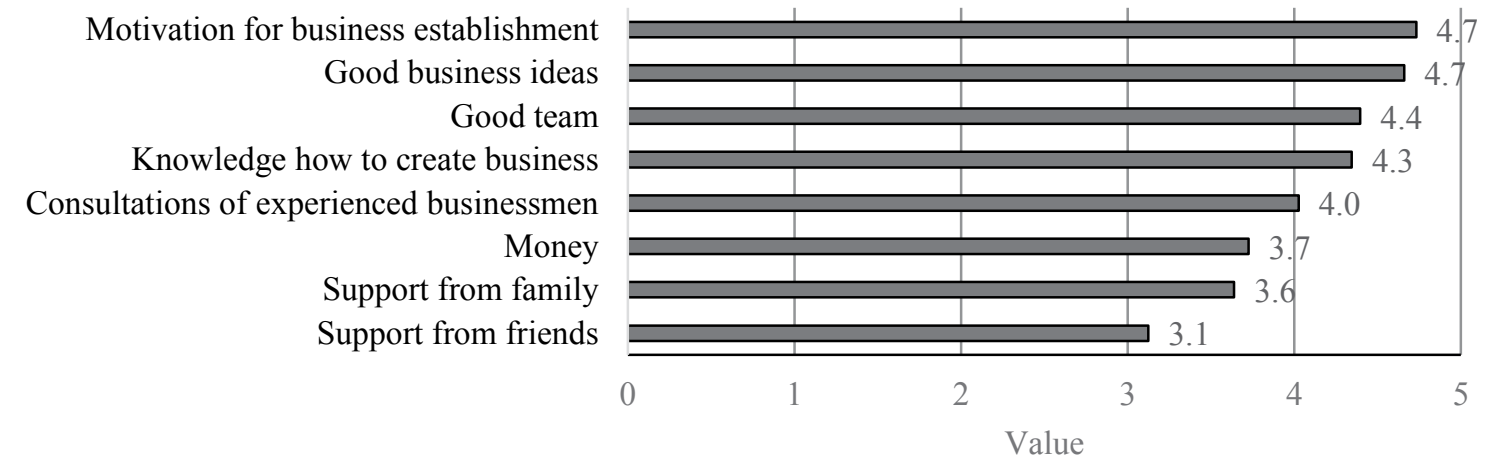

Figure 3. Factors Encouraging and Preventing Entrepreneurship. 


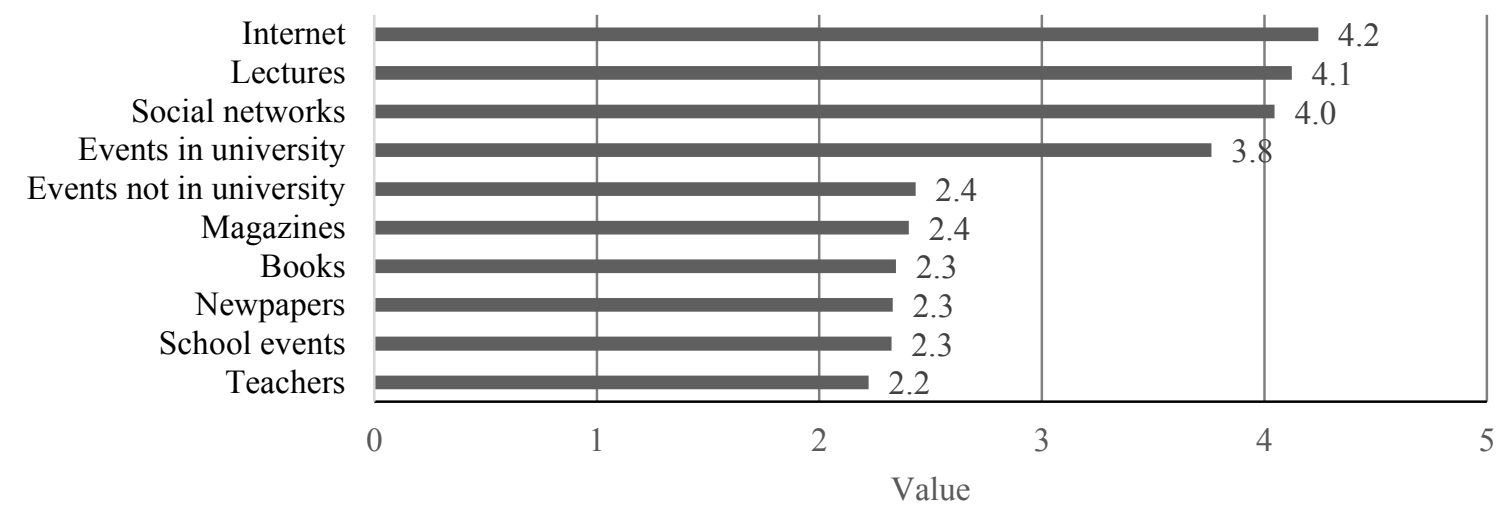

Figure 4. Information Sources Related to Entrepreneurship.

they will establish their own business (4.2 points). Respondents participating in research agree with the statement that your own business means a lot of work, little time; however, business carrier is attractive to respondents. In the theoretical part a factor of motivation was distinguished - the fact that this is an important factor is confirmed by the respondents - they think that they are motivated and try to fulfill their objectives. Also, it can be noted that respondents are determined to establish their own business in the future (4 points). The research data shows that respondents would be determined to establish their own business and put all efforts (4 points). However, it should be concluded that a good idea is necessary for business (this is stated by the respondents while answering the question presented earlier), but in this section, they state that they do not have business idea which they are willing to implement (2.2 points). The last question helped to determine the most important factors describing respondents' motivation to have business; however, the analysis has shown that many respondents do not have business idea, but they would like to have their own business.

The propose of the study is to assess the determinant factors and motives that influence students' entrepreneurial readiness. This is important for constructing success Entrepreneurship education model at university. This paper represents one of the few empirical analyses of the on-going debate how entrepreneurs can be developed. There are various factors that can influence readiness of young people towards entrepreneurial activities. As show Macke \& Markley (2003) entrepreneurs may want to create new venture due self-sufficiency, lifestyle, necessity or desire for wealth, some of them may be ready for new start-up business due ability to explore new area, attractiveness of business idea, entrepreneurship program, willingness to invest and ability to create entrepreneurial team. There are various components of entrepreneurial motivation. Woo, Cooper and Dunkelberg (2000) found that ability to obtain high profit and create successful new venture will generate higher motivation towards new business start-up. In addition to analyzing the use of various information sources the research question is formulated as follows: what kind of information sources can be used in the Entrepreneurship education model at university, that students can get information in the best way. The training should be more practical that theoretical. The entrepreneurship programmes should be more of real world activities. Students can get more useful knowledge and gain from success entrepreneurs' experiences if the training is more extensive. This may be done by allowing the students to do innovative business as practical. Entrepreneurship education model should assess the entrepreneurial capacity; discover the inner skills of the prospective entrepreneurs.

\section{Conclusions}

Entrepreneurship education in higher education institutions is considered to be a relevant area of research focus since on a theoretical level entrepreneurship education is treated as priority among various activities of educational bodies that encourages youth to establish their own business. Entrepreneurship education is often defined in the key institutional documents, however, problems arise in implementing goals. The major measures applied are study subjects integrated into the study process, seminars, events and conferences as well as mentoring and training. However, the performed theoretical analysis shows that although different measures are adopted by universities, the motivation of the target group (e.g. students') to have a specific mind-set of an entrepreneur and be eager to start a business is of the paramount significance. According to the theoretical analysis entrepreneurship becomes experienced and practical process. This type requires structural changes in educational system and new teaching methods.

The offered model demonstrates the constituent elements of entrepreneurship education at universities, however, the applicability and benefits of the model 
should be thoroughly explored as well. A special attention should be paid to identify the opportunities for students to come closer to the real business environment. The investigated students showed that their motives and factor encouraging entrepreneurship are good examples. To improve entrepreneurship education model for the future training we should conduct a teaching methods on how business can be set-up. This can be achieved by inviting successful entrepreneurs to share entrepreneurial knowledge. This research need to be continued in order to investigate the best ways and methods how success to share successful entrepreneurs experience to students. Further investigation should focus on the effectiveness of entrepreneurship education programs and the impact on motivating students to establish their own business.

\section{References}

1. Ansari, S., Bell, J., Iyer, B., \& Schlesinger, P. (2014). Educating entrepreneurial leaders. Journal of Entrepreneurship Education, 17(2), 31 - 51.

2. Driessen, M.P., \& Zwart, P.S. (2010). The entrepreneurial Scan Measuring Characteristics and Traits of Entrepreneurs. Retrieved February 28, 2017, from: http://www.entrepreneurscan.com/wpcontent/ uploads/2010/10/EScan-MAB-Article-UK.pdf.

3. Gegieckienè, L., \& Grikšienè, A. (2009). Verslo vadyba (Business management). Ciklonas, Vilnius.

4. Gamez, J. (2013). Entrepreneurship and creation of companies: theories, models and cases. Unisalle, Bogotá: Universidadde La Salle.

5. Herrera, O. (2010). Education for Entrepreneurship and Innovation. Training in Entrepreneurship in the Faculties of Administration in Bogota, 36 - 55.

6. Jaunimo galimybiu rinkodara (2015). (Youth Opportunities Marketing) Retrieved March 3, 2017, from: http://kurklt.lt/wp-content/uploads/2015/10/Jaunimo-u\%C5\%BEimtumo-priemoni\%C5\%B3-rinkodara.Pirmas-etapas.pdf. (in Lithuanian).

7. Jaunimo versluma vertinančiu priemoniu rinkinys (2013). (Youth entrepreneurship Valuation Toolkit). Retrieved March 3, 2017, from: http://www.esparama.lt/es_parama_pletra/failai/fm/failai/Vertinimas_ ESSP_Neringos/Ataskaitos_2011MVP/Jaunimo_verslumas_ataskaita.pdf. (in Lithuanian).

8. Ji, Z., \& Zhao, X. (2014). Analyzing elements of the employment and entrepreneurship practice education of collegestudents. Journal of Chemical and Pharmaceutical Research, 6(7), $803-807$.

9. Kasnauskienè, G. (2010). Statistika verslo sprendimai (Statistics Business Solutions). Vilniaus universitetas.

10. Kardelis, K. (2016). Moksliniu tyrimu metodologija ir metodai (Research methodology and techniques). Science and Encyclopaedia Publishing Center Vilnius.

11. Lietuvos Respublikos nutarimas (2012). Dèl 2014 - 2020 metų nacionalinès pažangos programos patvirtinimo. (Resolution of the Government of the Republic of Lithuania For the 2014 - 2020 national program progress confirmation). Retrieved February 28, 2017, from: https://www.e-tar.lt/portal/lt/legalAct/ TAR.31A566B1512D. (in Lithuanian).

12. Lahm, R.Jr., \& Rader, C.S. (2014). Technology and distance education entrepreneurship programs: An eight-point frame-work for best practice. Journal of Entrepreneurship Programs, 17(2), 101 - 117.

13. Macke, D., \& Markley, D. (2003). Readiness for entrepreneurship: Tools for energizing entrepreneurship. Central for Rural Entrepreneurship. Retrieved February 28, 2017, from: https://www.ruraleship.org.

14. Ortega, R.M., Cano, C.B., Salcido, C.N., Villarreal, M.D., Villarreal, D.F. (2014). Entrepreneurship from an institution of higher education in Mexico. Global Conference on Business and Finance Proceeding, $9(1), 1523-1537$.

15. Pérez, L. (2014). Curriculum and Entrepreneurship. Universidad de La Salle.

16. Rae, D. (2014). Graduate entrepreneurship and career initiation in 'New Era' economy. Journal of General Management, 40(1), 79 - 95.

17. Sánchez, J.C. (2011). Entrepreneurship: Introduction. Psicothema, 23(3), pp. 424 - 426.

18. Singh, R.P., \& Magee, B. (2001). Entrepreneurship education: Is there a growing crisis? In Proceedings of the 2001USASBE/SBIDA annual national conference.

19. Saeed, S., Muffatto, M., \& Yousafzai, S. (2014). A multi-level study of entrepreneurship education among Pakistani. University Students. ERJ, 4(3), 297 - 321. Retrieved March 1, 2017, from: http://repository. essex.ac.uk/15395/1/Saeed\%20et\%20al.\%202014_ERJ.pdf.

20. Täks, M., Tynjälä, P., Toding, M., Kukemelk, H., \& Venesaar, U. (2014). Engineering students' experiences in studying entrepreneurship. Journal of Engineering Education, 103(4), 573 - 598. DOI: 10.1002/ jee.20056. 
21. Woo, C.Y., Cooper,A.C., \& Dunkelberg, W.C. (2000). The development and interpretation of entrepreneurial typologies. An Elgar reference collection, United Kingdom.

22. Žydžiūnaitè, V., \& Sabaliauskas, S. (2017). Kokybiniai tyrimai: principai ir metodai (Qualitative research principles and methods). Leidykla Vaga, Vilnius. (in Lithuanian). 